\title{
Incorporating Flipped Learning in Teaching English Grammar for EFL Students Across Proficiency Levels
}

\author{
Arif Husein Lubis ${ }^{1 *}$ and Eri Rahmawati ${ }^{2}$
}

\author{
${ }^{1}$ Universitas Pendidikan Indonesia \\ ${ }^{2}$ Universitas Sultan Ageng Tirtayasa \\ *Corresponding author.Email: lubis_ah@upi.edu
}

\begin{abstract}
Previous research has reported that flipped learning can enhance the students' English skills and learning behaviors. However, some challenges remain mainly on the students' ignorance and demotivation due to increased workload that should be accomplished. Moreover, empirical evidence on the benefits of flipped learning across proficiency levels in EFL context is considerably scant. This study, therefore, reports on the incorporation of flipped learning in teaching grammar to 94 first-semester undergraduate students at a private university in South Jakarta, Indonesia. Embracing a quantitative and qualitative design, three grammar tests (pre- mid- and post-tests) were administered to explore the impact of flipped learning on the students' grammar skills across proficiency levels. A questionnaire with close-andopen-ended items was handed in to the students afterwards. The quantitative results demonstrated that the students' grammar skills increased from the mean score of the pre-test to that of the post-test across proficiency levels. The qualitative results justified such positive impact; regardless of the students' level of proficiency in English grammar because flipped learning could activate learning motivation, learner autonomy, and learning awareness. Limited vocabulary mastery, inability to manage the time, ignorance, and technical issues were still identified as the challenges in incorporating flipped learning in an EFL grammar class. Recommendations for future research are also presented.
\end{abstract}

Keywords: flipped learning, teaching grammar, grammar skills, Indonesian undergraduate EFL students, proficiency level

\section{INTRODUCTION}

Grammar skills for English as foreign language students are considered a vital constituent of communicative competence to possess. Communicative competence deals with the students' ability to develop the language knowledge manifested in grammar skills and the performance in applying the obtained knowledge [1]. By doing so, meaningful communication with other people in diverse contexts can be realized as the prime learning objective. Grammar skills pertain to the abilities to understand and apply a particular language system and grammatical rules that contribute to the successful meaning-making process [2] and the increased intelligibility in performing the four skills of English [3]. Hence, the selection of the teaching method considerably determines the output of the grammar learning for the sake of enhancing the students' communicative competence.

Flipped learning as an emerging instructional method in the Asian context has shown to be a counterstrategy of the conventional methods to teaching grammar in the EFL context. The traditional learning process is mostly teacher-centred [4]. While the teachers are the centre of attention and knowledge transmitters, the students act as the recipients and silent listeners. This leads to passivity in learning English grammar, which considerably influences the learning outcomes. The learning model also involves the generic stages where the teachers deliver the knowledge or input in the class, and the students do assignments and homework outside the class. Flipped learning, therefore, reinforces the inverted learning mode where the students independently deepen their knowledge in an online way before participating in more meaningful and productionoriented activities in the face-to-face (F2F) session [5]. The learning atmosphere is guided by the teachers to be active, dynamic, and interactive [6] (p. 1). Under those circumstances, the exploration of the incorporation of flipped learning in teaching English grammar in the EFL context is worth-taking.

\subsection{Flipped learning}

Flipped learning is commonly characterized as an instructional method which emphasizes on studentcenteredness and personalization through the inverted learning process [7]. The students are encouraged to be 
responsible and autonomous to enrich their subject knowledge that can be enhanced by the use of ICTbased learning media as the pre-class activity before the in-class activities to apply and strengthen their obtained knowledge.

However, the flipped learning model might not enliven the principle of flipped learning if the learning process is not driven by four pillars [8]. First, the learning environment should be flexible, which allows the teachers to make appropriate modifications as a continuous reflective practice and promotes students' interactions and learning progress. Second, the learning culture should open the opportunity for the teachers to involve the students in various meaningful activities and to monitor the process and provide feedback. Third, the contents must be curated or created and organized carefully to achieve the learning goals, presented by using an accessible learning platform. Fourth, teacher's professionalism should be maintained; serving as not only the knowledge transmitter but also the guide, the class manager, the fellow, and the designer [9].

\subsection{The merits of flipped learning in the EFL context}

A considerable body of research has examined the incorporation of the flipped model in EFL contexts. The flipped model has shown to be beneficial for students and teachers. The students report that they can develop the four skills of English [9] [10] [11] [12], the idiomatic expressions [13], and the skills for TOEIC [14].

Previous research has also demonstrated the significance of the flipped model in teaching grammar in the last five years. Al-Harbi and Alshumaimeri [15] examined to what extent flipped learning was effective to develop forty-three $(n=43)$ second-year secondary school EFL students' grammar performances and attitudes toward the learning process in Riyadh, Saudi Arabia. They found that the mean test score of the students from the experimental group increased more than their counterparts, but not significantly. The students reported that the teaching method encouraged them to be a communicative, collaborative, and autonomous language learner. Webb and Doman [16] conducted a larger experimental study on the effects flipped learning had on the development of sixty-four $(n=64)$ undergraduate students' grammatical skills and their attitudes toward it in Macau and the US universities. After the ten-week course, the results demonstrated that the students' post-test mean score from the experimental group outnumbered their counterparts. Regarding the attitudes, the students argued that they became more confident in learning the English grammar. Flipped learning was also perceived beneficial to develop their autonomy in learning English grammar. The positive effect of flipped learning on the development of students' grammar skills was also evident in the Indonesian higher education context. Saidah [17] conducted a study, involving sixty-one $(n=61)$ first-year ELT students at an Islamic institute. The statistical results showed that the students from the experimental group performed better than their counterparts. While the former group's mean score was 76.78 , the latter group's mean score was 49.45 .

\subsection{The challenges of incorporating flipped learning in the EFL context}

For the students, the workload may increase because the monologue teaching is not delivered during the class hours anymore. As a result, more student-centred activities such as discussions, hands-on assignments, and tests, to mention a few, are focused during the inclass and after-class sessions. The students may perceive the increased workload burdensome. One of the common effect of such perception is the increased ignorance and demotivation to learn among the students in the form of self- and imposed muting, for example [9]. The technical issues during the pre-class activities may also hinder the students' self-study and exploration process. For the teachers, the emphasis on the studentcenteredness and personalized learning process may cause burdensome as well because they have to design a flexible but constructive learning environment. This goal indeed consumes more time than the traditional learning design.

Although flipped learning is a promising instructional method to teaching English grammar, the exploration of the incorporation of such learning method in an EFL grammar class across proficiency levels still receives less attention. This study, therefore, aims to explore the incorporation of flipped learning to teach English grammar across the proficiency levels of the students in the Indonesian context. Hence, the following research questions guide this study.

1. What is the impact of incorporating flipped learning on the Indonesian undergraduate EFL students' grammar skills across proficiency levels?

2. How do the students perceive the incorporation of flipped learning in the grammar class?

\section{METHOD}

This classroom-based research employed a quantitative and qualitative design. The descriptive statistical results were used to address the impact of incorporating flipped learning on the students' grammar test scores. The questionnaire results were used to delineate the students' perceptions of the learning process within the flipped learning model. Since it was classroom-based research, the first author served as the lecturer as well. 


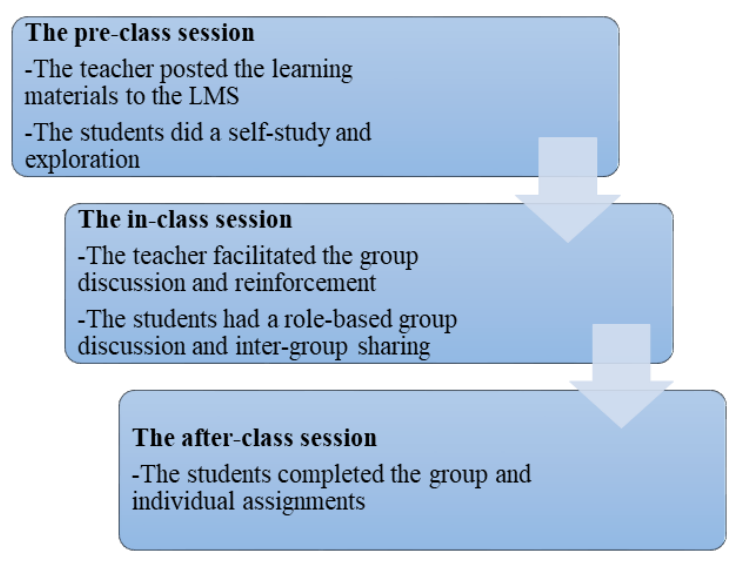

Figure 1 The flipped learning process

Ninety-four (94) of 102 first-year students majoring in information technology from a private university in South Jakarta, Indonesia, participated in this study. Also, only 84 students reported their English proficiency level taken from their English national examination scores and the length of learning English.

The course was aimed at enhancing the students' grammar skills for communicative purposes. Notably, the students were encouraged to have the ability to introduce themselves by using proper English grammar. This study was conducted for one semester comprising 16 meetings, each of which lasted for 1 hour 30 minutes. Figure 1 depicts the flipped learning process.

The students' scores were obtained from pre- midand post-tests by using Google Forms. The question items were then validated by an ELT lecturer whose expertise is in English grammar. After the post-test, 87 students filled out a 35 -item questionnaire (18 Likertscale; 17 short essays) made by the researchers administered by using Google Forms. It was intended to explore the students' perceptions of the advantages of the learning activities in the flipped learning process, the challenges, and the recommendations for future practices. The researchers employed the Indonesian language for the questionnaire items and allowed the students to give responses to the short-essay items using the same language to avoid misunderstanding and bias answers.
The students' scores of pre- and post-tests were calculated by performing descriptive statistics. The statistical measurement included mean, median, modus, the highest and lowest scores, and standard deviation. The Pearson product-moment correlation coefficient (r) was measured to test the validity of each questionnaire item (Field, 2009). All questionnaire items were valid because all Pearson coefficient values were above the $r$ table value $=0.271$ with 0.01 significance level $(2$ tailed). Additionally, all items had high reliabilities with the overall three coefficient values above 0.8 (Cronbach's $\alpha=0.915$, Spearman-Brown $=0.897$, Guttman split-half $=0.897$ ). The analysis of the qualitative data started with translating the students' short-essay responses into English. The transcripts were analysed by using an inductive thematic approach [18], involving open coding, labelling, and categorization processes iteratively to understand the patterns. Then, peer debriefing was conducted by inviting the same ELT lecturer to assure the validity and reliability of the final version of the categories [9].

\section{FINDINGS AND DISCUSSION 3.1. The impact of flipped learning on the Indonesian undergraduate EFL students' grammar skills across proficiency levels}

Figure 2 and Table 1 depict the descriptive statistics of the students' scores across the three tests.

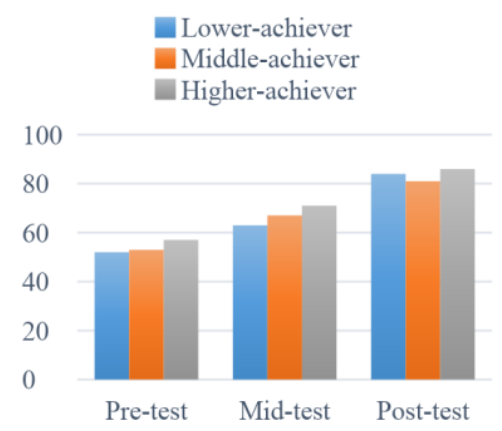

Figure 2 The students' grammar test scores.

Table 1. The descriptive statistics of the students' scores

\begin{tabular}{|l|c|c|c|c|c|c|c|c|c|c|}
\hline Category & $\overline{\bar{X}}$ PrT & Min & Max & $\overline{\bar{X}}$ MiT & Min & Max & $\overline{\bar{X}}$ PoT & Min & Max & $* \%$ of increase \\
\hline All classes & 54 & 12 & 90 & 67 & 43 & 85 & 84 & 67 & 100 & $55 \%$ \\
\hline Class A & 55 & 22 & 84 & 63 & 51 & 78 & 87 & 70 & 100 & $58 \%$ \\
\hline Class B & 55 & 12 & 90 & 68 & 43 & 85 & 83 & 70 & 98 & $51 \%$ \\
\hline Class C & 52 & 24 & 86 & 69 & 43 & 84 & 81 & 67 & 94 & $56 \%$ \\
\hline LA & 52 & 12 & 84 & 63 & 43 & 82 & 84 & 67 & 96 & $61 \%$ \\
\hline MA & 53 & 24 & 90 & 67 & 43 & 85 & 81 & 70 & 98 & $53 \%$ \\
\hline HA & 57 & 30 & 82 & 71 & 59 & 81 & 86 & 73 & 100 & $51 \%$ \\
\hline
\end{tabular}

Notes: PrT=Pre-test; MiT=Mid-test; PoT=Post-test; LA=Lower-achiever; MA=Middle-achiever; HA=Higher-achiever

*From pre-test to post-test 
All bar charts exemplified the development of the students' grammar skills with the range of percentage of increase $=51-61 \%$. While the lowest scores between the pre-test and post-test showed a highly significant number of interval $=55$, the number of the interval between the highest scores in both tests was only ten. The influence of the incorporation of flipped learning on the students' grammar skills in class A was the highest compared to the other two classes with the mean score of the post-test $=87$ and the highest score $=100$. Across the proficiency levels of the students, the impact of flipped learning on the students' grammar skills was gradually increasing in the mid-test. Surprisingly, however, the mean score of the post-test obtained by the lower-achievers was higher than that of the middleachievers.

The findings conform to the previous research in the Asian context [15] [16] and the Indonesian context [17]. The fact that the percentage of increase from the pre-test and post-test ranges from $51 \%$ to $61 \%$ reaches a higher significant gain on achievement than the threshold $40 \%$ exhibits a notable finding of the present study.

\subsection{The students' perceptions of the incorporation of flipped learning in the grammar class}

The students reported that it was the first time learning English grammar by using a flipped learning method supported by role-driven group discussion. Generally, the incorporation of flipped learning was preferred by the students with the mean $=3.72$ and $\mathrm{SD}=$ 0.858 . The following excerpts show their reasons.

At the first time, I was less able to follow this learning method. However, after several meetings, I can learn English better and learn to work in groups. (S77)

Flipped learning was considered helpful and useful to improve the students' grammar skills because it enabled them to enhance their understanding of the materials through the use of technologies. It also encouraged group works through peer sharing so that the individual student can identify the errors. The findings are corroborated by Singay [19], unveiling that the Bhutanese students perceived flipped learning as a helpful method to promoting a conducive learning atmosphere, technology use, and collaboration.

However, of 87 students, $5 \%$ of them did not prefer flipped learning to learn English grammar.

I don't really like it. It is because everyone has their own preference to learn something and they have different styles. (S26)

One of the students argued that the process of absorbing the materials given through the flipped model was not maximum enough. The student insisted $t s$ that a direct explanation from the lecturer in class is perceived better.

\subsubsection{Flipped learning and motivation}

The development of students' grammar skills was associated with their increased learning motivation. Flipped learning was perceived helpful to elevate their motivation to learn English $($ mean $=3.70, \mathrm{SD}=0.864)$ and to learn English grammar (mean $=3.91, \mathrm{SD}=$ 0.741). Moreover, it triggered motivation to perform actively in the grammar class (mean $=3.83, \mathrm{SD}=$ 0.735).

I prefer to be reinforced to look for and understand the materials by myself instead of being explained by the lecturer. I like that. (S50)

Flipped learning ignites the challenging, interesting, and insightful learning atmosphere. As a result, the combination of self-study and group discussion can develop their motivation to perform better in the grammar class. The findings corroborate $\mathrm{Hsieh}, \mathrm{Wu}$, and Marek [13], who found that flipped learning can trigger more participation from the students.

Notwithstanding the increased motivation, some of the students confirmed that flipped learning was not considerably influential for the development of their motivation to learn English (9\%) and to learn English grammar (4\%). First, they still preferred the teachercentred learning, where the teacher becomes the main knowledge transmitter. Second, although the English language has been the primary language of technology, the students' motivation to learn English grammar might not be automatically aroused.

\subsubsection{Flipped learning and learning autonomy}

The questionnaire results revealed that they became more autonomous in the pre-class activities including: learning English grammar $($ mean $=3.82, \mathrm{SD}=0.858)$, searching for supporting materials (mean $=4.05, \mathrm{SD}=$ 0.746), and understanding the materials from the lecturers (mean $=3.78, \mathrm{SD}=0.754)$ and other sources (mean $=3.86, \mathrm{SD}=0.702)$. The students also viewed flipped learning as a medium to enhance their autonomy in doing the tasks (mean $=4.06, \mathrm{SD}=0.688$ ) and managing the time to finish the tasks (mean $=3.91$, SD $=0.741$ ). Moreover, it was believed to be helpful to develop their capacities in solving the encountered difficulties (mean $=3.93, \mathrm{SD}=0.712$ ) and their confidence to ask for help to their friends during the stressful situation $($ mean $=3.76, \mathrm{SD}=0.876)$.

Yes, that's true. I become more diligent to learn the English lessons. So, I manage myself to search for and understand the materials one day before the inclass activities. (S13)

The findings are in line with Al-Harbi and Alshumaimeri [15], who underscore the self-exploration triggered by flipped learning. They become self-alarmed to prepare the best for the role-driven group discussion in the pre-class activities. Some other students reported that their time management skill and capability in autonomously accomplishing the task was elevated by flipped learning as found in Tsai's [20] study. The 
findings indicate that flipped learning triggers more student-student interaction and self-evaluation driven by reflective thinking to develop their problem-solving skills as part of the manifestations of learner autonomy [20].

\subsubsection{Flipped learning and learning awareness}

The students perceived flipped learning as a useful means of realizing their English proficiency level (mean $=4.10, \mathrm{SD}=0.822$ ). Hence, they admitted that they became more aware of their responsibility to develop their English skills (mean $=4.20, \mathrm{SD}=0.790$ ). Such circumstances resulted in the increasing initiatives to help their friends encountering any difficulties in understanding the materials $($ mean $=4.10, \mathrm{SD}=0.732)$ and in accomplishing the assignments (mean $=4.13, \mathrm{SD}$ $=0.696$ ). Accordingly, interactive communication among the students intensified when they encountered difficulties (mean $=3.60, \mathrm{SD}=1.005)$, albeit not significantly positive.

Because in every in-class activity, there is a roledriven group discussion. I have my own responsibility. So, if I do not accomplish my own role tasks, I will be the troublesome for my group. (S5)

This circumstance resonates with the principle of cooperative learning [21] [22] that promotes positive interdependence, individual accountability, and equal participation. In other words, ignorance and self-muting in doing the tasks, as found in the previous research [15], can be lessened. It is strengthened by the shortessay questionnaire results where they help their friends to understand the learning topics, get access to the materials, understand the contents, understand the assigned roles and the tasks, participate actively in the in-class activities, and solve the encountered problems.

\subsubsection{The challenges of incorporating flipped learning}

The short-essay questionnaire results showed that the lack of ability to understand the assigned roles was mentioned by $25.80 \%$ of the students. Meanwhile, lack of vocabulary mastery was admitted by $53.90 \%$ of them, which might hinder the process of understanding the materials. One of the students expressed, "Sometimes, I wanted to ask to my friends about the materials. However, they also do not master the vocabularies. So, I was confused to understand the materials." The student sometimes did not have the opportunity to get clear answers from his friends. This indicates that during the in-class collaborative activities, teachers should consider the heterogeneous technique in dividing the students into groups.

Time management became another issue for $19 \%$ of students. It was corroborated by Abdul, asserting that "The time allocation limits our discussion, so that sometimes the process is quite unstructured." Moreover, although the students perceived the roledriven group discussion helpful to train them to be cooperative students as the primary in-class activity in the flipped learning, around $31 \%$ of students admitted that their group mates were not cooperative enough. Miftah, for example, experienced a blatant effect from such uncooperative conditions in which sometimes some of his friends asked him to accomplish their assignments. This circumstance implies that the flipped learning method supported by role-driven group discussion may not significantly lessen the state of ignorance or the practice of academic dishonesty of the students.

Concerning the technology use, the short-essay questionnaire results revealed that most students still bothered to the lack of Wi-Fi support from the campus to access the Moodle and YouTube. The lack of Wi-Fi support also caused unstable bandwidth of the internet connection, which led to many buffering times. Most of the students accessed the internet by using their smartphones or laptops by tethering the internet connection from their phones. The limited internet charge, therefore, can hinder the process of understanding the materials.

\section{CONCLUSION}

This study has explored the impact of incorporating flipped learning on the Indonesian undergraduate EFL students' grammar skills along with their perceptions of flipped learning. The results demonstrate that flipped learning can be a potential means of elevating the students' grammar skills because it activates learning motivation, learner autonomy, and learning awareness. This study contributes to the availability of evidence on the quantitative and qualitative exploration of incorporating flipped learning in an EFL classroom in the higher education context. However, more rigorous research involving a multidisciplinary approach is worth-taking to continue the discussion. This study has also proved that albeit not significantly, the role-driven group discussion in the in-class activity enables the students to lessen several challenges during the flipped learning process such as ignorance or self-muting and demotivation to accomplish the tasks. However, it is admitted that the inability of flipped learning to cater for all students' needs with diverse learning styles and strategies is still evident in this context. Thus, future endeavours to maximize the incorporation of flipped learning to encounter those limitations are highly recommended.

\section{AUTHORS' CONTRIBUTIONS}

Arif Husein Lubis develops the research design, collects and analyses the data, makes the first draft of the paper. Eri Rahmawati proofreads the analysis results and improvises the paper.

\section{ACKNOWLEDGMENTS}

We would like to thank all the participants for their consent and cooperativeness during the research. 


\section{REFERENCES}

[1] Hedge, T. (2002). Teaching and learning in the language classroom. Oxford, UK: Oxford University Press.

[2] Cuéllar, M. T. A. (2013). Process writing and the development of grammatical competence. HOW: A Colombian Journal for Teachers of English, 20, 11-35.

[3] Azar, B. (2007). Grammar-Based teaching: A practitioner's perspective. TESL-EJ, 11(2), 1-12.

[4] Ismail, A. S. A. (2010). ESP Students' Views Of ESL Grammar Learning. GEMA Online ${ }^{T M}$ Journal of Language Studies, 10(3), 143-156.

[5] Davies, R. S., Dean, D. L., \& Ball, N. (2013). Flipping the classroom and instructional technology integration in a college-level information systems spreadsheet course. Education Tech Research Dev, 61(4), 563-580.

[6] Flipped Learning Network. (2014b). What is flipped learning? Retrieved from http://fln.schoolwires.net/cms/lib07/

VA01923112/Centricity/Domain/46/

FLIP_handoutFLN_Web.pdf

[7] Bergmann, J., \& Sams, A. (2012). Flip your classroom: Reach every student in every class every day. Eugene, OR: International Society for Technology in Education.

[8] Flipped Learning Network. (2014a). The four pillars of F-L-I-P. Retrieved from http://www.flippedlearning.org/cms/ lib07/VA01923112/Centricity/Domain/46/ FLIP_handout_FLN_Web.pdf

[9] Amiryousefi, M. (2017). The incorporation of flipped learning into conventional classes to enhance EFL learners ' L2 speaking, L2 listening, and engagement. Innovation in Language Learning and Teaching, 13(2), 1-15. https://doi.org/10.1080/17501229.2017.1394307

[10] Afrilyasanti, R., Cahyono, B. Y., \& Astuti, U. P. (2016). Effect of flipped classroom model on Indonesian EFL students' writing ability across and individual differences in learning. International Journal of English Language and Linguistics Research, 4(5), 65-81.

[11] Lee, G., \& Wallace, A. (2018). Flipped learning in the English as a foreign language classroom: Outcomes and perceptions. TESOL Quarterly, 52(1), 62-84. https://doi.org/10.1002/tesq.372

[12] Wu, W.-C. V, Hsieh, J. S. C., \& Yang, J. C. (2017). Creating an online learning community in a flipped classroom to enhance EFL learners' oral proficiency. Educational Technology \& Society, 20(2), 142-157.

[13] Hsieh, J. S. C., Wu, W. V., \& Marek, M. W. (2016). Using the flipped classroom to enhance EFL learning. Computer Assisted Language Learning, 30(1-2), 1-21. https://doi.org/10.1080/09588221.2015.1111910

[14] Obari, H., \& Lambacher, S. (2015). Successful EFL teaching using mobile technologies in a flipped classroom. Proceedings of the 2015 EUROCALL Conference, 433-438. https://doi.org/10.14705/ rpnet.2015.000371

[15] Al-Harbi, S. S., \& Alshumaimeri, Y. A. (2016). The flipped classroom impact in grammar class on EFL Saudi secondary school students , performances and attitudes. English Language Teaching, 9(10), 60-80. https://doi.org/10.5539/elt.v9n10p60

[16] Webb, M., \& Doman, E. (2016). Does the flipped classroom lead to increased gains on learning outcomes in ESL/EFL contexts? The CATESOL Journal, 28(1), 39-68.

[17] Saidah. (2019). The effectiveness of flipped classroom in teaching grammar of EFL students. Journal of English Teaching and Research, 4(2), 193-206.

[18] Creswell, J. W. (2012). Educational research: planning, conducting, and evaluating quantitative and qualitative research. Boston, MA: Pearson Education.

[19] Singay. (2020). Flipped learning in English as a second language classroom: Bhutanese students' perceptions and attitudes of flipped learning approach in learning grammar. Indonesian Journal of Applied Linguistics, 9(3), 666-674. https://doi.org/10.17509/ijal.v9i3.23217

[20] Tsai, Y. (2019). Promotion of learner autonomy within the framework of a flipped EFL instructional model: Perception and perspectives. Computer Assisted Language Learning, 1-32. https://doi.org/10.1080/09588221.2019.1650779

[21] Foldnes, N. (2016). The flipped classroom and cooperative learning: Evidence from a randomised experiment. Active Learning in Higher Education, $17(1)$ 39-49. https://doi.org/10.1177/1469787415616726

[22] Ning, H. (2011). Adapting cooperative learning in tertiary ELT. ELT Journal, 65(1), 60-70. https://doi.org/10.1093/elt/ccq021 